\title{
Pelaksanaan Program Usaha Kesehatan Sekolah (UKS) di Sekolah Dasar se-Kecamatan Telanaipura Kota Jambi Tahun 2018
}

\author{
The Implementation of School Health Unit at Elementary School District of \\ Telanaipura Jambi
}

\author{
Herwansyah $^{1}$, Andy Amir ${ }^{1}$, Oka Lesmana $S^{1}$ \\ ${ }^{1}$ Program Studi Ilmu Kesehatan Masyarakat Fakultas Kesehatan Masyarakat Universitas Jambi
}

\begin{abstract}
Abstrak
Pentingnya kegiatan UKS ini didukung dengan fakta bahwa kelompok usia sekolah di Indonesia merupakan kelompok usia yang paling besar populasinya. Besarnya jumlah populasi kelompok umur anak sekolah ini, tentu berisiko terhadap kontribusi permasalahan kesehatan masyarakat. Adapun beberapa risiko gangguan kesehatan yang rentan diderita oleh kelompok usia sekolah antara lain Kekurangan Energi Kronis (KEK), pendek/stunting, obesitas, penyakit tidak menular, gangguan jiwa emosional, percobaan bunuh diri, dan bullying. Peran UKS dalam hal ini adalah memberdayakan siswa dan komunitas sekolah agar membiasakan berperilaku hidup bersih dan sehat yang dapat mengurangi faktor risiko kejadian gangguan kesehatan. Jenis penelitian ini adalah gabungan antara penelitian kuantitatif dan kualitatif, dengan tujuan secara deskriptif untuk mengetahui pelaksanaan program Usaha Kesehatan Sekolah (UKS) di Sekolah Dasar se-Kecamatan Telanaipura Kota Jambi Tahun 2018. Penelitian dilakukan di Sekolah Dasar Negeri dan Sekolah Dasar Swasta yang ada di Kecamatan Telanaipura, Kota Jambi, yang berjumlah 39 Sekolah. Populasi dalam penelitian ini adalah seluruh Guru pembimbing UKS di 39 Sekolah Dasar yang ada di Kecamatan Telanaipura, Kota Jambi, seluruh sampel dalam penelitian ini, Total Sampling. Pelaksanaan Usaha Kesehatan Sekolah di SD Se-Kecamatan Telanaipura Kota Jambi dalam kategori baik. Hal ini terlihat dari beberapa indicator sebagai berikut: (1) Pelaksanaan pendidikan dan penyuluhan kesehatan di sekolah termasuk dalam kategori sangat baik. (2) Pelaksanaan pelayanan kesehatan di sekolah termasuk dalam kategori baik. (3) pelaksanaan lingkungan sekolah yang sehat termasuk dalam kategori baik.
\end{abstract}

\begin{abstract}
The importance of school health unit has been proven by the fact that most of population in Indonesia are in adolescent age. This obviously lead to the high prevalence of both communicable and noncommunicable disease. There are some health problems amongst this group, including protein deficiency, stunting, as well as related to mentally illness. The school health unit plays important role in empowering students to have proper health behaviour and awareness. This was a descriptive study analysed the implementation of school health unit at elementary schools in Telanaipura. The sample was teachers who have responsibility in school health unit activity. The implementation of school health unit has been categorised as very good implementation. The health services was also adequate and the implementation of health school program has been well-planned and well-applied.
\end{abstract}

Korespondensi: Herwansyah

Email: herwansyah.unja@gmail.com 


\section{Pendahuluan}

$2014 \begin{gathered}\text { Peraturan Bersama } 4 \text { Menteri tahun } \\ \text { tentang Pembinaan dan }\end{gathered}$

Pengembangan Usaha Kesehatan Sekolah (UKS) menjelaskan bahwa Pembinaan dan Pengembangan UKS adalah upaya pendidikan dan kesehatan yang dilaksanakan secara terpadu, sadar, berencana, terarah dan bertanggung-jawab dalam menanamkan, menumbuhkan, mengembangkan dan membimbing untuk menghayati menyenangi dan melaksanakan prinsip hidup sehat dalam kehidupan sehari-hari. Program ini merupakan program terpadu 4 Kementerian: Kementerian Pendidikan dan Kebudayaan, Kementerian Kesehatan, Kementerian Dalam Negeri, dan Kementerian Agama. ${ }^{1}$ Melalui beberapa peraturan, menunjukkan bahwa pemerintah telah dan sedang berusaha meningkatan derajat kesehatan masyarakat, termasuk masyarakat sekolah. Termasuk didalamnya dalam rangka mencerdaskan kehidupan bangsa dan demi tercapainya tujuan pendidikan nasional sangat ditunjang oleh kesehatan peserta didik di suatu lembaga pendidikan. Untuk mendukung terciptanya peserta didik yang sehat, sekolah dapat merealisasikan dengan mengaktifkan program usaha kesehatan sekolah yang bertujuan untuk meningkatkan kesehatan yang optimal sehingga dapat memaksimalkan potensi dan prestasi anak untuk belajar. Program ini terdiri dari tiga kegiatan utama yang disebut dengan Trias Usaha Kesehatan Sekolah meliputi aspek pendidikan kesehatan, pelayanan kesehatan, serta pembinaan lingkungan kehidupan sekolah yang sehat. ${ }^{2}$

Usaha kesehatan sekolah merupakan usaha kesehatan masyarakat yang dijalankan di sekolah-sekolah dengan anak didik beserta komunitas lingkungan sekolah sebagai sasaran utama. Guru UKS dan peserta didik adalah merupakan anggota primernya, masyarakat sekolah atau orang tua siswa, serta perawat komunitas dalam hal ini petugas kesehatan dari puskesmas menjadi pendukung pelaksana keberhasilan program kesehatan sekolah (Nasrul Effendi, 1998). Pentingnya kegiatan UKS ini didukung dengan fakta bahwa kelompok usia sekolah di Indonesia merupakan kelompok usia yang paling besar populasinya. Kelompok umur $5-9$ tahun berjumlah hampir 24 juta orang, kelompok umus 10 - 14 tahun sebesar lebih dari 22 juta jiwa, dan rentang umur 15 - 19 tahun berkisar diangka 20 juta orang. ${ }^{3}$

Besarnya jumlah populasi kelompok umur anak sekolah ini, tentu berisiko terhadap kontribusi permasalahan kesehatan masyarakat. Adapun beberapa risiko gangguan kesehatan yang rentan diderita oleh kelompok usia sekolah antara lain Kekurangan Energi Kronis (KEK), pendek/stunting, obesitas, penyakit tidak menular, gangguan jiwa emosional, percobaan bunuh diri, dan bullying .

Peran UKS dalam hal ini adalah memberdayakan siswa dan komunitas sekolah agar membiasakan berperilaku hidup bersih dan sehat yang dapat mengurangi faktor risiko kejadian gangguan kesehatan. Fenomena ini didukung oleh data hasil survei global kesehatan pelajar berbasis sekolah tahun 2015 bahwa faktor risiko kesehatan anak usia sekolah paling besar dikontribusi oleh perilaku merokok sebesar hampir 50\%, diikuti oleh perilaku seksual diusia dini 5\%, konsumsi minuman beralkohol sebesar $4,4 \%$, dan mengkonsumsi NARKOBA $1,7 \%$ (GSHS, 2015). Definisi lain menjelaskan bahwa usaha kesehatan sekolah adalah usaha kesehatan masyarakat 
yang dijalankan di sekolah-sekolah, dengan sasaran utama adalah anak-anak sekolah dan lingkungannya. ${ }^{4}$

Dalam upaya meningkatkan kemampuan hidup sehat dan derajat kesehatan peserta didik sedini mungkin, dijalankan mulai dari sekolah dasar sampai sekolah lanjutan, sekarang pelaksanaannya diutamakan di sekolah dasar. Hal ini disebabkan karena Sekolah Dasar merupakan komunitas (kelompok) yang sangat besar, dan rentan terhadap berbagai risiko terjadinya penyakit, dan merupakan dasar bagi pendidikan selanjutnya.

Kegiatan yang dilaksanakan melalui masyarakat sekolah dipandang lebih efektif dibanding kegiatan lain yang dilakukan dalam masyarakat umum, didasari pada pertimbagan: (a) sekolah dasar mempunyai komunitas peserta didik yang sangat besar; (b) tersebar luas di seluruh pelosok tanah air; (c) anak lebih peka terhadap perubahan dan pembaharuan ; (d) pembiayaan yang dikeluarkan oleh pemerintah dalam kesehatan lehih ekonomis.

Berdasarkan data dari Dinas Pendidikan Kota Jambi tahun 2017, jumlah Sekolah Dasar adalah 230 SD yang tersebar di 11 kecamatan. Kecamatan Telanaipura, yang merupakan daerah pusat pemerintahan dan pendidikan, memiliki 39 SD yag terdiri dari SD Negeri dan SD milik Yayasan (Dinas Pendidikan, 2017). Berdasarkan observasi awal di 10 SD seKecamatan Telanaipura, bahwa pelayanan kesehatan di beberapa sekolah sudah optimal, namun beberapa lainnya masih belum menunjukkan optimalisasi program, khususnya di SD milik pemerintah khususnya dilihat dari tenaga guru yang belum terlatih. Selanjutnya pendanaan untuk program UKS belum merata di sekolah-sekolah yang dibuktikan dari sarana maupun prasarana yang belum memadai. Ada sekolah yang belum mempunyai ruang UKS permanen, perlengkapan dan peralatan UKS yang tidak layak pakai, masalah sanitasi dan pembuangan. Untuk program usaha kesehatan sekolah diperlukan kerja tim yang efisien dan efektif untuk memberikan hasil yang optimal.

\section{Metode Penelitian}

Jenis penelitian ini adalah gabungan antara penelitian kuantitatif dan kualitatif, dengan tujuan secara deskriptif untuk mengetahui pelaksanaan program Usaha Kesehatan Sekolah (UKS) di Sekolah Dasar se-Kecamatan Telanaipura Kota Jambi Tahun 2018. Penelitian akan dilakukan di Sekolah Dasar Negeri dan Sekolah Dasar Swasta yang ada di Kecamatan Telanaipura, Kota Jambi, yang berjumlah 39 Sekolah. Penelitian ini dilakukan selama 6 (Enam) bulan terhitung dari bulan Juni 2018 sampai dengan bulan Oktober 2018.

Populasi dalam penelitian ini adalah seluruh Guru pembimbing UKS di 39 Sekolah Dasar yang ada di Kecamatan Telanaipura, Kota Jambi. Sampel dalam penelitian ini adalah guru pembimbing UKS. Seluruh SD (Negeri dan Swasta) akan dijadikan sebagai sampel dalam penelitian ini, Total Sampling. Tim peneliti juga melibatkan pihak PUSKEMAS yang bertanggung jawab atas program UKS di Kecamatan Telanaipura sebagai informan tambahan.

Analisis yang digunakan Deskriptif Kuantitatif. Analisis deskriptif dimaksudkan untuk memperjelas data yang 
diperoleh dengan cara mendeskripsikan atau menggambarkan data tersebut. Analisis deskriptif yang dibahas adalah mengenai hasil perhitungan melalui pendekatan kuantitatif. Untuk pendekatan kualitatif, data diolah dengan teknik content analysis. ${ }^{7,8}$ Tim peneliti menggunakan panduan pertanyaan, lembar observasi dan kuesioner yang dikembangkan dari penelitian-penelitian sebelumnya tentang pelaksanaan UKS di Sekolah Dasar dan dikombinasikan dengan panduan dari Kementerian Kesehatan.

\section{Hasil dan Pembahasan}

\section{a. Pendidikan Kesehatan.}

Dalam rangka untuk mengetahui pendidikan kesehatan di SD SeKecamatan Telanaipura Kota Jambi maka dilakukan dengan mengungkap permasalahan-permasalahan yang dikemukakan oleh guru pendidikan jasmani dan kesehatan di setiap SD. Pendidikan kesehatan dinyatakan dalam kategori sangat baik apabila presentase yang diperoleh antara $95 \%$ sampai $100 \%$, dalam kategori baik bila terdapat antara $88,9 \%$ sampai $94,99 \%$, dalam kategori cukup baik bila antara $83,2 \%$ sampai $88,8 \%$ dan masuk kategori kurang baik jika antara 77,5 sampai $83,1 \%$. Hasil penelitian tentang pendidikan kesehatan SD SeKecamatan Telanaipura Kota Jambi berdasarkan hasil analisis diperoleh rata-rata skor 35,10 dengan presentase $87,8 \%$. Karena berada pada rentang presentase $83,2 \%$ hingga $88,8 \%$, maka kegiatan pendidikan kesehatan di SD Se-Kecamatan Telanaipura Kota Jambi termasuk dalam kategori cukup baik. SD Se-Kecamatan Telanaipura Kota
Jambi sudah melaksanakan pendidikan kesehatan dengan kategori sangat baik yaitu sebesar 35\%, dengan kategori baik sebesar 5\%, kemudian dengan kategori cukup baik sebesar $5 \%$ dan dengan kategori kurang baik sebesar 55\%. Dengan demikian secara umum dapat dijelaskan bahwa pendidikan kesehatan di SD Se-Kecamatan Telanaipura Kota Jambi telah berjalan dengan kurang baik.

\section{b. Pembinaan Lingkungan Sekolah}

Pembinaan Lingkungan Sekolah dinyatakan dalam kategori sangat baik apabila presentase yang diperoleh antara 93,9\% sampai $100 \%$, dalam kategori baik antara $87,6 \%$ sampai $93,8 \%$ dalam kategori cukup baik antara $81,3 \%$ sampai $87,5 \%$ dan dalam kategori kurang baik antara $75 \%$ sampai $81,2 \%$. Hasil penelitian tentang Pembinaan Lingkungan Sekolah di SD SeKecamatan Telanaipura Kota Jambi berdasarkan hasil analisis diperoleh ratarata skor 34,90 dengan presentase $87,3 \%$.

Karena berada pada rentang presentase $81,3 \%$ hingga $87,5 \%$, maka pembinaan lingkungan sekolah di SD Se-Kecamatan Telanaipura Kota Jambi termasuk dalam kategori cukup baik. sebagian besar pembinaan lingkungan sekolah di SD Se-Kecamatan Telanaipura Kota Jambi dengan kategori sangat baik sebesar 35\%, dengan kategori baik sebesar $0 \%$, kategori cukup baik sebesar 20\% dan yang masuk dalam kategori kurang baik sebesar $45 \%$. Dengan demikian secara umum dapat dijelaskan bahwa pembinaan lingkungan sekolah di SD Se-Kecamatan Telanaipura Kota Jambi tersebut kurang baik. 


\section{c. Pelayanan Kesehatan}

SD se-Kecamatan Telanaipura Kota Jambi sudah melaksanakan pelayanan kesehatan dengan kategori sangat baik yaitu sebesar 35\%, dengan kategori baik sebesar $10 \%$, kategori cukup baik sebesar 30\%, dan kategori kurang baik sebesar $25 \%$. Dengan demikian secara umum dapat dijelaskan bahwa pelayanan kesehatan di SD seKecamatan Telanaipura Kota Jambi tersebut sangat baik.

Pelayanan Kesehatan di 39 SD seKecamatan Telanaipura Kota Jambi berjalan dengan baik, dimana upaya peningkatan kesehatan (promotif) dengan memberikan penyuluhan mengenai kesehatan gizi dan menjaga kesehatan pribadi, pencegahan (preventif) dengan pemeriksaan kesehatan secara periodik untuk memantau serta memelihara kesehatan peserta didik, pengobatan (kuratif) dengan pengobatan ringan dan pemberian rujukan medis serta pemulihan (rehabilitatif) telah diterapkan di 39 SD se-Kecamatan Telanaipura Kota Jambi.

\section{Kesimpulan}

a. Pelaksanaan Usaha Kesehatan Sekolah di SD Se-Kecamatan Telanaipura Kota Jambi dalam kategori baik. Hal ini terlihat dari beberapa indicator sebagai berikut: (1) Pelaksanaan pendidikan dan penyuluhan kesehatan di sekolah termasuk dalam kategori sangat baik. (2) Pelaksanaan pelayanan kesehatan di sekolah termasuk dalam kategori baik. (3) pelaksanaan lingkungan sekolah yang sehat termasuk dalam kategori baik. b. Faktor pendukung pelaksanaan UKS di SD se-Kecamatan Telanaipura Kota Jambi meliputi penanaman pengetahuan tentang pola hidup sehat terhadap peserta didik secara rutin serta adanya dukungan dan koordinasi pelaksanaan mekanisme organisasi UKS dan pelaksanaan program kerja UKS baik dari sekolah maupun dari tim Pengawas Pembina UKS di Kecamatan Telanaipura, sedangkan faktor penghambat pelaksanaan UKS meliputi kurang adanya partisipasi atau dukungan dari orang tua dan masyarakat terhadap kegiatan UKS di sekolah dan masih terbatasnya sarana dan prasarana pendukung pelaksanaan program UKS seperti ruang UKS yang kurang memenuhi syarat dan tersedia apa adanya. Serta ketersediaan toilet di sekolah yang masih kurang karena masih jauh dari jumlah yang standar yaitu ada 1 toilet setiap 20 siswa.

\section{Daftar Pustaka}

1. Keputusan Bersama Menteri Pendidikan Nasional, Menteri Kesehatan,Menteri Agama, dan Menteri Dalam Negeri Republik Indonesia Nomor 1/U/SKB/2003, Nomor 1067/MENKES/SKB/VII/2003, Nomor MA /230 A/2003, Nomor 26 tahun 2003 tentang Pembinaan dan Pengembangan Usaha Kesehatan Sekolah.

2. Kementerian Kesehatan, 2017, Peraturan Menteri Kesehatan tentang Penyelenggaraan Program Indonesia Sehat dengan Pendekatan Keluarga.

3. Soenarjo, 2002, Usaha Kesehatan Sekolah, Bandung: Remaja Rosdakarya 
4. R.J Soenarjo, 2002, Usaha Kesehatan Sekolah, Jakarta, PT. Remaja Rosdakarya.

5. Mu'rifah dan Hardianto Wibowo. 2006. Pendidikan Kesehatan. Jakarta. Kementerian Pendidikan dan Kebudayaan.

6. Drajat Martianto. 2005. Menjadikan UKS Sebagai Upaya Promosi Tumbuh Kembang Anak Didik. Yogyakarta: Gajah Mada University Press

7. Sugiyono, 2009, Metode Penelitian Kuantitatif, Kualitatif, $R \& D$, Bandung: Rosdakarya.

8. Universitas Jambi, 2018, Panduan Pelaksanaan Penelitian dan Pengabdian Kepada Masyarakat Edisi II Tahun 2018, Jambi: Lembaga Penelitian dan Pengabdian Masyarakat 